\title{
Nuclear DNA in the determination of weighing factors to estimate exergy from organisms biomass
}

\author{
Júlio C. Fonseca $^{\mathrm{a}, 1}$, João C. Marques ${ }^{\mathrm{a}, *}$, Artur A. Paiva ${ }^{\mathrm{b}}$, \\ Albertina M. Freitas ${ }^{b}$, Vítor M.C. Madeira ${ }^{c}$, Sven E. Jørgensen ${ }^{d}$ \\ a IMAR-Institute of Marine Research (IMAR), Department of Zoology, University of Coimbra, 3000 Coimbra, Portugal \\ ${ }^{\mathrm{b}}$ Histocompatibility Centre of Centre-Faculty of Medicine, University of Coimbra, 3000 Coimbra, Portugal \\ ${ }^{\mathrm{c}}$ Department of Biochemistry, University of Coimbra, 3000 Coimbra, Portugal \\ d Department of Environmental Chemistry, Royal Danish School for Pharmacy, Denmark
}

\begin{abstract}
The application of ecological exergy as a suitable system-oriented development indicator of ecosystems and the estimation proposals from biomass are revised. DNA contents ( $C$-values) of several groups of organisms are figured, either determined by flow cytometry or taken from literature. The applicability of DNA contents for determination of weighing factors to estimate ecological exergy from the biomass of organisms, as proposed by [Marques, J.C., M.Â. Pardal, S.N. Neilsen, S.E. Jørgensen, 1997. Analysis of the properties of exergy and biodiversity along an estuarine gradient of eutrophication. Ecol. Model. 102: 155-167.], is discussed and putative values for these weighing factors $(\beta)$ are presented. This proposal is discussed in theoretical and practical aspects, concerning reliability and eventual application in ecological 'exergetic' studies. (C) 2000 Elsevier Science B.V. All rights reserved.
\end{abstract}

Keywords: System ecology; Thermodynamics; Exergy estimation; DNA content; Biomass; Weighing factors

\section{Introduction}

Fluctuations in external factors (e.g. resources, physical and chemical parameters) determine the evolution of ecosystems and are exacerbated by human interference. Changes may occur at different levels of the ecosystem structure, including species composition; consequently, energy (quan-

\footnotetext{
* Corresponding author. Tel.: + 351-39-836386; fax: + 35139-823603.

E-mail address: jcmimar@cygnus.ci.uc.pt (J.C. Marques)

${ }^{1}$ fonseca@ci.uc.pt
}

tity and quality) transfer processes will be affected, in addition to interactive changes among internal populations (e.g. trophic relations) (Søndergaard et al., 1990; Zhou et al., 1996; Jørgensen and Padisak, 1996; Marques et al., 1997; Jørgensen and Nielsen, 1998b). These alterations comprise the regulatory responses of ecosystems to fluctuations of the external controlling factors (forcing functions).

Ecosystems, as self-organising systems in the Prigoginean sense (Prigogine, 1980), use high quality energy as 'fuel' in metabolic processes of matter and energy conversion (Schrödinger, 
1944), where the quality of energy relates to the ability to perform work. Energy flows for the maintenance and building up new structures, and ecosystems deviate from thermodynamic equilibrium returning low quality energy that results in entropy increase of the surroundings (Wall, 1986; Schneider and Kay, 1994a; Jørgensen and Nielsen, 1998b). Therefore, capability of ecosystems for processing information and energy is 'conditioned' by the forcing functions, and the thermodynamic analysis of ecosystems may help to understand the effects of external changes in development. Studies relating the structure of ecosystems with the capacity of energy processing and information are of obvious interest. Consequently, considerable attention has been devoted to the development of different ecological indicators aiming to characterize the structure and function of ecosystems during development. These ecological indicators may be understood as important measurable properties that are regularly optimized during the development of ecosystems. Several different indicators have been proposed and suggested as useful parameters to characterize the structure and function of systems under study (Bass, 1998; Bröring and Wiegleb, 1998; Jørgensen and Nielsen, 1998a,b;Marques et al., 1998a; Patten, 1998; Svirezhev, 1998; Ulanowicz, 1998). Exergy, as an ecological quantitative indicator derived from thermodynamics, is a central concept expressing energy with a built-in attribute of quality (Jørgensen and Mejer, 1977, 1979, 1981; Jørgensen, 1992a). This function is related but not identical to thermodynamic free energy. As free energy, it also estimates the maximum capacity of energy to perform useful work as the system proceeds to equilibrium with surroundings (Brzustowski and Golem, 1978; Ahern, 1980. Quoted from: Schneider and Kay, 1994a). In an opposed direction, it also reflects the quality of energy understood as the contrast or the distance to the thermodynamic equilibrium (Schneider and Kay, 1994b; Jørgensen and Nielsen, 1998a).

Thermodynamic analysis of ecosystems indicates an increased energy degradation either with more evolved or less perturbed ecosystems; on the other hand, a decreased ability to dissipate incoming energy may be verified in the ecosystem under stress (Schneider and Kay, 1995). Therefore, in terms of evolution, ecosystems are expected to evolve towards a state of optimal exergy configuration (Jørgensen, 1992b,c), improving to withdraw the exergy content of energy (Schneider and Kay, 1994a,b). It has been suggested that variations of exergy may express changes in ecosystem structure or components, and the application of exergy as a suitable system-oriented indicator of ecosystem states of development and health has been proposed (Nielsen, 1990; Jørgensen, 1994; Jørgensen et al., 1995; Fuliu, 1997; Marques et al., 1997, 1998a,b; Müller, 1997).

Although some earlier suggestions pointed out to the estimation of ecological exergy contents of structurally complex materials (Shieh and Fan, 1982), the discrimination between organisms different in structure and evolution is not accounted for. Thus, Mejer and Jørgensen (1979) proposed the ecological estimation of exergy in terms of a global summation of components of an ecosystem with through-flow, where each term would take into account the relative concentration of the corresponding component and its 'distance' from a reference state (the same component at thermodynamic equilibrium). To overcome the problem of defining reference states for different components under different conditions, Jørgensen et al. (1995) suggested approximate calculations which could take into account the higher organization of some organisms and consequently its higher contribution to the exergy estimation. Based on the assumption of a common reference state (detritus or dead organic matter), these authors provided an approach for the approximated estimation of ecological exergy in terms of the probability $\left(P_{i}\right)$ of producing organic matter (detritus) and the probability of 'selecting' its corresponding 'genetic information' $\left(P_{i, a}\right)$, for each component, as follows:

$E x \approx-R \cdot T \cdot \sum_{i}^{N} c_{i} \cdot \ln \left(P_{i}\right)$

with $P_{i}=P_{1} \cdot P_{i, a}$ and $P_{i, a}=20^{-700 g}$, where $R$ is the gas constant, $T$ the absolute temperature, $c_{i}$ the concentration in the ecosystem of the component $i$ and $700 \cdot g$ stands for an average value for the number of encoded amino-acids in the 
genome of species $i$. By means of thermodynamic formulations, this equation can be reorganized and the resulting function permits to estimate an ecological 'index' of exergy as follows (Jørgensen et al., 1995):

$$
\begin{aligned}
E x / R \cdot T= & \left(\mu_{1}-\mu_{1}^{\mathrm{eq}}\right) \cdot \sum_{i=1}^{N} c_{i} / R \cdot T \\
& -\sum_{i=2}^{N} c_{i} \cdot \ln P_{i, a}
\end{aligned}
$$

The use of exergy in Ecology, requires the estimation of the relative amount corresponding to the amount of biomass, $c_{i}$. Since the detritus is assumed as the reference state, rather than the thermodynamic equilibrium, and the probabilities estimated according to 'ecological' considerations, this function should be preferably designated as 'ecological exergy', to distinguish it from the formal thermomechanical definition of exergy/ availability. With reasonable approximations, it can be computed as:

$E x / R \cdot T \approx \Sigma \beta_{i} \cdot c_{i}$

where $c_{i}$ is the biomass concentration of species $i$ and $\beta_{i}$ is a weighing factor expressing the 'quantity of information' embedded in the biomass (Jørgensen and Nielsen, 1998a). This expression allows to compute this ecological function associating to ecosystems its composition and biological structure (information), and it may be taken as an operative estimate for the 'distance' to a reference state assumed as a reference environment, where all components are inorganic and homogeneously distributed without gradients. Consequently, choosing detritus as a reference level (i.e. $\beta=1$ ), the 'genetic information' content of organisms may be used to estimate $\beta$ for different organisms (taking $\beta$ as a discriminator of the organizational level of organisms relatively to detritus reference level). Therefore, it has been proposed to take into account the number of genes to determine the different exergy conversion factors $(\beta)$ (Jørgensen et al., 1995). Nevertheless, this proposal requires the knowledge of the total number of genes for many species, data not available for most species. In the absence of these data, calculations are processed on the basis of rough estimates.
It has been suggested to use nuclear DNA contents of organisms ( $2 C$-values or $C$-values, for diploid or haploid genomes, respectively) in the determination of the parameters $(\beta)$, as a more operational approach for the estimation of exergy from organism biomass (Marques et al., 1997). The determination of $C$-values for the different organisms is easily performed after suitable modifications of available laboratory methodologies.

In this article, we describe $C$-values for several organisms from different groups, either from published data or laboratory work and putative values of $\beta$ are calculated. Additionally, the proposal described by Marques et al. (1997) is discussed in terms of theoretical and practical aspects, concerning its feasibility and eventual application in ecological 'exergetic' studies.

\section{Methodologies}

The estimation of the nuclear DNA content of an organism is achieved by means of different techniques, namely Feulgen scanning microspectrophotometry (microdensitometry), chemical extraction, nuclear volume ratios, and reassociation kinetics, but flow cytometry (FCM) is the method of choice (Gailbraith et al., 1983 and Gailbraith, 1989). This technique requires separated single cells or isolated nuclei preparations. After the stoichiometric staining of particles with a fluorochrome specific for DNA, the measurement of the fluorescence associated with each particle permits to estimate its content in DNA.

The information collected by the flow cytometer can be displayed graphically on a data display, generally in the form of a histogram, with a horizontal and a vertical axis displaying the amount of DNA per cell (arbitrary units) and the number of particles at each amount of DNA, respectively (Shapiro, 1995). In general, the estimates of nuclear DNA contents are provided in picograms (pg) of DNA $\left(1 \mathrm{pg}=10^{-12} \mathrm{~g}\right)$ or in base pairs (bp) of double-stranded DNA. Each strand is a linear polynucleotide chain consisting of four nucleotides (A-adenine, G-guanine, Tthymine and $\mathrm{C}$-cytosine, two purines and two pyrimidines, respectively), and it is commonly ac- 
cepted an average molecular weight for each of the four nucleotides of ca. $618 \mathrm{D}$. The conversion factors are: $1 \mathrm{bp}=1.02 \times 10^{-9} \mathrm{pg}=618 \mathrm{D}(\mathrm{Li}$ and Graur, 1991). Thereby, concerning the estimation of the nuclear DNA from a new sample, quantification is performed by reference to nuclei internal standards (e.g. chicken red blood cells; CRBC $2 C=2.33 \mathrm{pg}$ ). This process calibrates the data in terms of absolute DNA units (e.g. pg or bp) (Rayburn, 1993).

The nuclear DNA content (2C-values) of macrofauna organisms from the Mondego estuary (Portugal) was determined by FCM. Individuals were collected and immediately carried to the laboratory, where they were kept alive until proceeding with FCM determinations. Just before experiments, animals were vigorously washed with deionized water and cooled on ice. Muscles or gill tissues were localized, dissected and small tissues samples excised, sometimes under microscope, and kept in cooled filtered $(0.45 \mu \mathrm{m})$ and sterile deionized water for short periods, to disrupt the cells by osmotic shock.

After few minutes, tissue samples were further disrupted by hand, and the presence of isolated cells and nuclei checked under microscope. Cell debris were sedimented (brief centrifugation) and the topmost of nuclei suspension was collected by suction with a syringe. Nuclei were then sedimented by centrifugation and, after ressuspention in sterile phosphate buffer saline containing $0.1 \%$ Triton X-100, fixed with $0.1 \%$ formaldehyde for ca. $30 \mathrm{~min}$ on ice. For FCM measurements, $1 \mathrm{ml}$ samples of isolated nuclei suspension were prepared containing $30 \mu \mathrm{g}$ of propidium iodide (PI), $30 \mu \mathrm{l}$ of RNAase-I (1\%), and approximately $10^{6}$ nuclei (in the proportion of 3:1 of target cells to internal standard), staining this suspension in the dark, at about $30^{\circ} \mathrm{C}$. Measurements were performed with a Coulter ${ }^{\circledR}$-Epics ${ }^{\circledR}$ XL flow cytometer. Alignment and calibration of the instrument were performed according to the manufacturer instructions prior to the measurements. Fluorescence was measured with a signal resolution of 1024 channels and evaluated on a linear scale. Each measurement was repeated 3-4 times and each recorded histogram represent ca. 10000 analysed nuclei. With the internal reference stan- dards, the DNA content per diploid nuclei ( $2 C$ value) of each individual (pg/diploid nuclei) was calculated, taking into account the fluorescence peak channels corresponding to $G_{0}-G_{1}$ cell populations of test $\left(T_{\text {est }}\right)$ and reference standard $\left(R_{\mathrm{ef}}\right)$, and the known DNA content of the standard $\left(S_{\text {DNA }}\right)$, as: $\left(T_{\text {est }} / R_{\text {ef }}\right) \times S_{\text {DNA }}$. Reference standards were chosen, in each situation, preventing the overlap of the fluorescence values for the reference and target cells (Fig. 1). FCM methodologies permit to discriminate different levels of ploidy $(2 C, 4 C, \ldots)$ in samples from polyploid organisms. Values $2 C$ were determined, assuming $C=(2 C) / 2$ in calculations.

We will now discuss the relations of Jørgensen et al. (1995) and Marques et al. (1997) proposals, in view of ecological exergy estimation.

The calculations developed by Jørgensen et al. (1995) to estimate the parameter $\beta$, considered the 'coding capacity of genome' in terms of the number of encoded amino acids figured in Eq. (1) as ' $700 \cdot g$ ', where ' $g$ ' stands for the assumed number of genes for each organism and '700' the average number of amino acids corresponding to each gene. Therefore, ' $700 \cdot g$ ' is the number of encoded amino acids. Alternatively, Marques et al. (1997) suggested the use of nuclear DNA content to evaluate the parameter $\beta$, assuming DNA content as a measure of the 'information content' of its genome, acquired along the evolutionary process from which it has been selected. It is conceivable that the proposals are related at the level of ' $P_{i}$ ', determination $\left(P_{i}=P_{1} \cdot P_{i, a}\right.$, where $\left.P_{i, a}=20^{700 g}\right)$ or the determination of the 'probability' associated with the 'genetic information content' of organisms.

Considering prokaryotes and lower eukaryotes, the minimum genome size found in each phylum increases with the increasing complexity of organism structure ('structural complexity'), as illustrated in Table 1 (Levin, 1994); 'complexity' is understood as the amount of study/information needed to describe a system and 'structure' as the number of 'parts' and the framework of organism 'construction'. However, as documented in Table 2, similar organisms (in 'complexity') may have significantly different nuclear DNA contents (MacGregor, 1982; Gold et al., 1992), and, at 
higher evolutionary levels, genome size loses correspondence to the increase in 'structural complexity' of organisms, due to the presence of repetitive DNA sequences (Levin, 1994). These findings are the basis of the $C$-value paradox ( $\mathrm{Li}$ and Graur, 1991). Furthermore, although the non-repetitive DNA contents increase with the overall genome size, up to $C$-values of approximately $3 \times 10^{9} \mathrm{bp}$ ( $3.3 \mathrm{pg}$; typically of mammals), it tends to a limiting plateau of ca. $2 \times 10^{9} \mathrm{bp}$ (approximately $2 \mathrm{pg}$ ) (Table 1 ). Thus, accordingly to Levin (1994), organism complexity should be better evaluated by non-repetitive DNA content, rather than the total genome, in the estimation of the probability $P_{i}$. For instance, it could be assumed, as a working hypothesis, that to each adjacent triplet of nucleotides from non-repetitive DNA corresponds a transcribed RNA-signal (from regulatory genes or structural genes). Hence, as a topmost limit, the non-repetitive DNA could be considered as an approximate estimate (although rough) of the overall 'coding capacity' of the genome (corresponding to ' $700 \cdot g$ ' in Jørgensen et al. (1995) proposal) and used in

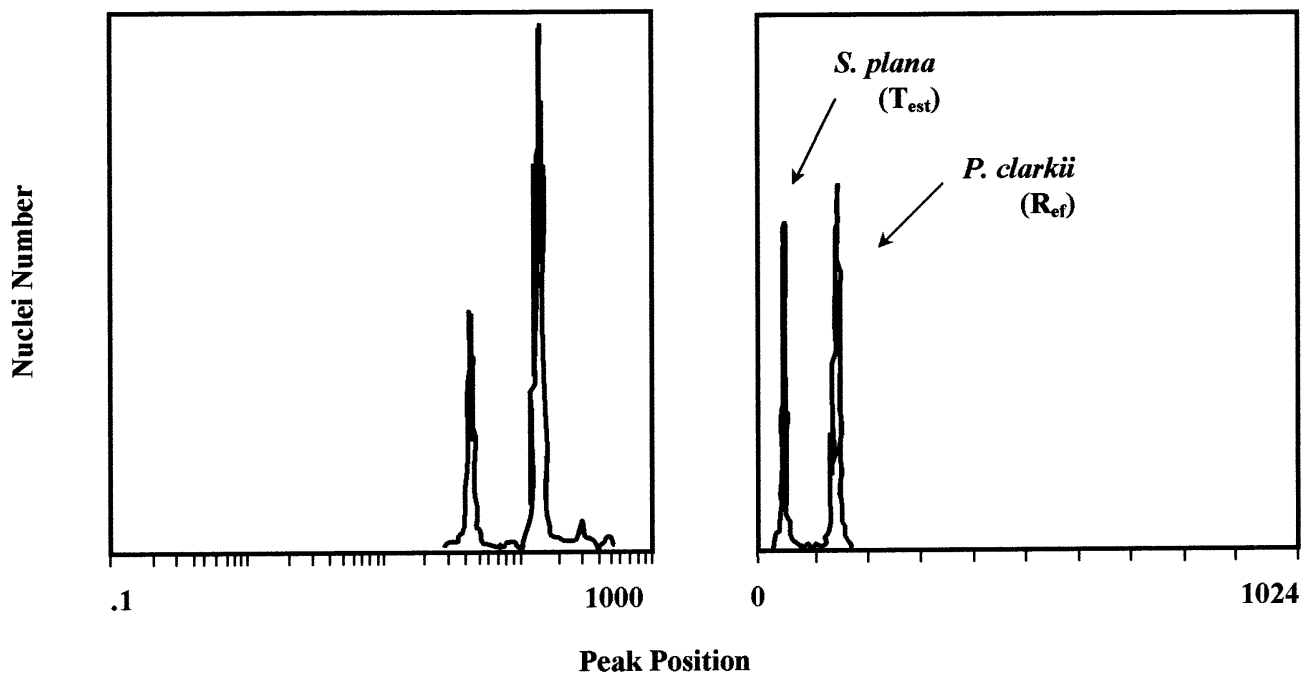

Fig. 1. Example for comparison between the nuclear DNA content of two different species determined by FCM. Comparison of peak positions, taking into account the known DNA content of nuclei of the crayfish $P$. clarkii, here considered as internal standard, allows to estimate the $2 C$-value of the nuclei of the bivalve $S$. plana, here considered as the sample. Peaks correspond to $G_{0}-G_{1}$ cell populations of sample $\left(\mathrm{T}_{\mathrm{est}}\right)$ and the reference standard $\left(\mathrm{R}_{\mathrm{ef}}\right)$.

Table 1

Overall DNA content ( $C$-value) and corresponding nonrepetitive DNA content (in terms of pg of DNA and as percentage of the total DNA content) $)^{\mathrm{a}}$

DNA content $(\mathrm{pg})$

\begin{tabular}{llccc}
\cline { 3 - 5 } Group & Organism & \multicolumn{1}{c}{$C$-value } & Nonrepetitive DNA & \% of total genome size \\
\hline Bacterium & E. coli & $4.3 \times 10^{-3}$ & $4.3 \times 10^{-3}$ & 100 \\
Nematode & C. elegans & $8.2 \times 10^{-2}$ & $6.7 \times 10^{-2}$ & 82 \\
Insect & D. melanogaster & $14.3 \times 10^{-2}$ & $10.2 \times 10^{-2}$ & 71.4 \\
Mammals & H. sapiens & 3.37 & 2.04 & 60.6 \\
Plants & N. tabaccum & 3.88 & 1.28 & 33
\end{tabular}

\footnotetext{
a Although nonrepetitive DNA component increases with the total genome size, it reaches a plateau at ca. 2 pg (see: Levin, 1994).
} $1 \mathrm{pg}=0.98 \times 10^{9}$ bp. Sources: Levin, 1994; Li and Graur, 1991; Cavalier-Smith, 1985; and others. 
Table 2

Overall (haploid) DNA content for different groups of organisms $^{\mathrm{a}}$

\begin{tabular}{ll}
\hline Organisms & $\begin{array}{l}\text { DNA content } \\
\text { (pg) } C \text {-value }\end{array}$ \\
\hline
\end{tabular}

Annelida

Polychaeta

Spionida

Spionidae

Prionospio malmgreni $\quad 0.55$

Capitellidae

Notomastus latericeus $\quad 1.32$

Phyllodocida

Phyllodocidae

Nereiphylla paretti

Hesionidae

Ophiodromus obscurus $\quad 1.6$

Ophiodromus culveri $\quad 0.35$

Kefersteinia sp. $\quad 0.22$

Hesiospina $\mathrm{sp.} \quad 0.53$

Nereididae

Platynereis dumerilii $\quad 1.0$

Laeonerteis culveri $\quad 0.8$

Nereis succinea $\quad 2.2$

Nereis diversicolor $\quad 2.3$

Neanthes caudata $\quad 2.25$

Nephtydae

Nephtys incisa $\quad 7.2$

Nephtys sp. $\quad 2.2$

Glyceridae

Glycera americana $\quad 3.5$

Glycera lapidum $\quad 1.46$

Eunicida

Onuphidae

Onuphis eremita oculata $\quad 1.7$

Onuphis sp. $\quad 2.0$

Diopatra cuprea cuprea $\quad 2.0$

Americonuphis magna $\quad 2.0$

Lumbrineridae

Lumbrineris tenuis $\quad 2.4$

Ninoe nigripes $\quad 5.3$

Terebellida

Pectinariidae

Pectinaria gouldii

Sabellida

Sabellidae

Amphiglena mediterranea $\quad 0.39$

Branchiomma luctuosum $\quad 1.2$

Branchiomma crispum $\quad 1.3$

Myxicola infundibulum $\quad 1.6$

Sabella apallanzanii $\quad 0.65$

Echinodermata

Asteroidea

Forcipulata

Asteriidae

Marthasterias glacialis

0.6

Echinoidea

Diadematoida

Arbaciidae

Arbacia lixula
Mollusca

Gastropoda

Archeogastropoda

Pattelidae

Pattela sp.

Trochidae

Gibbula umbilicallis

1.1

Mesogastropoda

Hidrobiidae

Peringia ulvae

0.68

Littorinidae

Bivalvia

Littorina littorea

1.1

Veneroida

Cardiidae

Cerastoderma edule

Scrobiculariidae

Scrobicularia plana

Veneridae

Ruditapes decussata Nenerupis Pullastra

Maetridae

Spisula solidissima $\quad 1.16$

Mytiloida

Mytilidae

Mytilus

galloprovincialis

Ostreida

Ostreidae

Ostrea edulis

1.81

1.78

Pterioida

Pectinidae

Pecten maximus Chlamys opercularis

Arthropoda

Crustacea

Maxillopoda

Thoracica

Pollicipedidae Pollicipes pollicipes

Amphipoda

Gammaridae

Echinogammarus

marinus

Isopoda

Cyathura carinata

Spharomatidae S. hookeri

Decapoda

Crangonidae

Crangon crangon

Portunidae

Insecta

Carcinus maena

Diptera

Chironumus sp.

Pisces

Salmo gairdneri irideus 2.5

Oncorhynchus mykiss 2.49

Cyprinus carpio $\quad 1.94$

Lampreia planeri $\quad 1.73$

a Approximate figures are given. Sources: Cavalier-Smith, 1978; Li and Graur, 1991; Gambi et al., 1997; Fonseca et al., 1998 ; and others. $\left(1 \mathrm{pg}=0.98 \times 10^{9} \mathrm{bp}\right)$. CRBC $(2 C=2.33 \mathrm{pg})$. 
the evaluation of the parameter $\beta$, accordingly to Jørgensen et al. (1995) and Marques et al. (1997).

However, data of the non-repetitive fraction of genome are too scarce to be applied in the estimation of ecological exergy. Thus, at the present, as a preliminary approach regarding the applicability of the $C$-values (considered here as $C=2 C / 2$ ) in the determination of $\beta$ and regarding to the $C$ value paradox, the minimum genome size (lowest $C$-value) for each group of organisms (taxon) is preferable than the $C$-value for each species in the group. This could provide an upper limit for the organism complexity in the group, reducing hopefully the uncertainty from the presence of repetitive DNA fractions in the genome.

The minimum DNA contents (lowest $C$-values) of several groups of organisms are listed in Table

3. These data may be used in the estimation of the $\beta$ parameter, according to the Eq. (1) and the proposal of Jørgensen et al. (1995). Below, a model is described to estimate the exergy from the biomass of macrofauna.

As an example, the estimation of $\beta$ for the biomass of the annelid $N$. diversicolor can be worked as follows:

lowest $C$-value for the group Annelids: $0.07 \mathrm{pg}$ convert to nucleotides (as base-pairs; bp): 1 $\mathrm{pg}=0.98 \times 10^{9} \mathrm{bp}$

$C^{*}=6.86 \times 10^{7}$ bp

(in the 'double stranded DNA')

$\downarrow$

only one polynucleotide chain is considered ('single stranded DNA'), which corresponds to half of this value:

$$
C^{* *}=\left(C^{*} / 2\right)=3.43 \times 10^{7} \text { (nucleotides). }
$$

Table 3

Values for the number of genes and cell types and for the weighing factor $\left(\beta^{*}\right)$ to estimate exergy related to organisms biomass according to Jørgensen et al. (1995), for different groups of organisms

\begin{tabular}{|c|c|c|c|c|c|}
\hline Organisms & N. genes ${ }^{\mathrm{a}}$ & N. cell types ${ }^{\mathrm{a}}$ & $\beta^{*}$ & Lowest $C$-value & $\beta^{* *}$ \\
\hline Detritus & 0 & - & $1^{\mathrm{b}, \mathrm{c}}$ & - & 1 \\
\hline Bacteria & 600 & $1-2$ & $3^{\mathrm{b}, \mathrm{c}}$ & $0.0017^{\mathrm{d}}$ & 2 \\
\hline Algae & 850 & $6-8$ & $3-4^{b, c}$ & $0.04^{\mathrm{d}}$ & 25 \\
\hline Fungi & 3000 & $6-7$ & $10^{\mathrm{b}, \mathrm{c}}$ & $0.005^{\mathrm{d}}$ & 3 \\
\hline Annelids & $10500 ; 100000^{\mathrm{c}}$ & 60 & $35^{\mathrm{b}} ; 287^{\mathrm{c}}$ & $0.07^{\mathrm{e}}$ & 50 \\
\hline Crustaceans & - & - & $144^{\mathrm{c}}$ & $0.35^{f}$ & 230 \\
\hline Molluscs & - & - & $287^{\mathrm{c}}$ & 0.43 & 280 \\
\hline Gastropods & - & - & - & $0.68^{f}$ & 450 \\
\hline Bivalves & - & - & - & $1.16^{\mathrm{f}}$ & 760 \\
\hline Echinoderms & - & - & $144^{\mathrm{c}}$ & $0.54^{\mathrm{d}}$ & 360 \\
\hline Chordates & - & - & - & $0.20^{\mathrm{d}}$ & 130 \\
\hline Birds & 120000 & - & $344^{\mathrm{b}} ; 390^{\mathrm{c}}$ & $1.7^{\mathrm{d}}$ & 1100 \\
\hline Mammals & 140000 & 100 & $402^{\mathrm{c}} ; 430^{\mathrm{b}}$ & $3.0^{\mathrm{d}}$ & 2000 \\
\hline H. sapiens & - & - & - & $2.0^{\mathrm{g}}$ & 1300 \\
\hline
\end{tabular}

${ }^{\text {a }}$ It is presented, also, the lowest $C$-values in the groups of organisms and the corresponding weighing factor $\left(\beta^{* *}\right)$ accordingly to the proposal in this article.

${ }^{\mathrm{b}}$ Values provided in Jørgensen et al., 1995; Jørgensen et al., 1998.

${ }^{\mathrm{c}}$ Figures presented by Marques et al. (1997).

${ }^{\mathrm{d}}$ Figures representing the lowest values in the group according to Cavalier-Smith (1978).

e Values from Gambi et al. (1997).

${ }^{\mathrm{f}}$ Values from Table 2 presented in this article.

$\mathrm{g}$ Values from Table 1 presented in this article. 
As hypothesized, the 'maximum coding capacity' is estimated from the number of nucleotides triplets (as a topmost limit):

$\downarrow$

$$
C^{* * *}=\left(C^{* *} / 3\right)=\left(3.43 \times 10^{7}\right) / 3=1.14 \times 10^{7}
$$

$\downarrow$

This value $\left(C^{* * *}\right)$ is applied to estimate ' $\ln P_{i, a}$, (instead of ' $700 \cdot g_{i}$ )

(see Eq. (2))

$$
\downarrow
$$

$\ln P_{i, a}=\ln 20^{-C^{* * *}}=3.42 \times 10^{7}$

and finally this value is used in Eq. (2) to estimate $E x / R \cdot T$

Following the calculations according to the proposal of Jørgensen et al. (1995), it is assumed an average molecular weight for detritus of 100000 , and the free energy released per $\mathrm{g}$ of organic matter (detritus) is ca. $18.5 \mathrm{~kJ} / \mathrm{mol}$. Taking $T=300 \mathrm{~K}$ and $R \approx 8.3 \mathrm{~J} / \mathrm{mol} \cdot \mathrm{K}$, Eq. (2) estimates the corresponding 'index' of ecological exergy (expressed in terms of ' $g$ detritus exergy equivalents'). This means (operatively) that the obtained value is divided by $7.43 \times 10^{5}$, assumed as the contribution of detritus in terms of $\mathrm{g} / \mathrm{l}$, accordingly to Eq. (2):

$$
\begin{aligned}
& E x / R \cdot T \approx \ldots c_{\text {Annelids }} \times\left(3.42 \times 10^{7}\right)+\ldots \\
&+\left(c_{\text {Detritus }}+\ldots+c_{\text {Annelids }}+\ldots\right) \\
& \times\left(7.43 \times 10^{5}\right) \\
&(\text { exergy 'equivalents', g/1 }) \\
&(\text { 'normalizing') } \\
& E x / R \cdot T \approx \ldots c_{\text {Annelids }} \times(50)+\ldots+c_{\text {Detritus }} \\
&(\text { exergy 'equivalents', g Detritus } / 1)
\end{aligned}
$$

It follows that the contribution to the ecological exergy 'index' from an organism of the considered group (Annelids) can be calculated as:

$$
E x_{\text {Annelids }} / R \cdot T \approx c_{\text {Annelids }} \times(50)\left(\beta_{\text {Annelids }} \approx 50\right),
$$

where $c_{\text {Annelids }}$ is the biomass of the organism (i.e. concentration in the ecosystems in $\mathrm{g} / \mathrm{l}$ ) and $\beta_{\text {Annelids }}$ the corresponding weighing factor for the group Annelids.
The values for the DNA content ( $C$-values) of several groups are given in Table 2, including data either determined by FCM methodology or taken from literature. Table 3 lists the lowest values for the haploid DNA contents in several groups of organisms, accordingly to Cavalier-Smith (1978). Additionally, it also lists values for $\beta$, the weighing factor to estimate exergy associated to the biomass of organisms, obtained according to Jørgensen et al. (1995) and based in the $C$-values.

\section{Discussion and concluding remarks}

The application of ecological exergy is very promising in ecosystem analysis and putatively in environmental management. The methodologies to estimate exergy balance of ecosystems (Jørgensen and Mejer, 1979, 1981; Jørgensen et al., 1995; Marques et al., 1997) have been developed on the basis of thermodynamic principles (Bendoricchio and Jørgensen, 1997) and reflect the importance of these principles at different levels of hierarchical biological systems, from cells to assembling of organisms and ecosystems. Nevertheless, it is hardly difficult to generate thermodynamic data in the exact physicochemical context. Due to the high level of complexity, the measurement of reliable thermodynamic quantities in ecosystems is practically unfeasible and assumptions are required to estimate the thermodynamic balance of these systems.

Ecosystem structure and energy-matter balance are expected to evolve, conditioned by the prevailing environmental parameters, to a state of optimal thermodynamic balance (Marques et al., 1998b). The ecological exergy does not correspond exactly to the thermomechanical availability functions (i.e. the work potential of a system at a certain state relatively to the state of equilibrium with the environment-dead state), but is an operative system interpretation proportional to the available energy invested by ecosystem in building up its 'structure' (information and mass). Ecosystems evolve with an optimized storage of the available energy (Jørgensen, 1992b,c; Jørgensen, 1997) and increase its dissipation to maintain the levels of biomass and (higher) com- 
plexity, during development (Schneider and Kay, 1994a,b, and 1995), far from the thermodynamic equilibrium. At the organism level, more 'complex' (structure) organisms are, in principle, associated to larger information content, also corresponding to larger distances from thermodynamic equilibrium (Marques et al., 1998b). The estimation of exergy associated to organisms biomass (ecological exergy) is achievable, provided that the corresponding weighing factors $(\beta)$ for different organisms are known. Determination of this parameter represents the main issue of Jørgensen et al. (1995) and Marques et al. (1997) proposals.

The contribution to the ecological exergy of the 'genetic information' may be estimated by the method of Jørgensen et al. (1995), but it requires data for the number of genes (Table 3), which, at the present, are very unreliable. Estimates of approximately 6000 genes for Drosophila, fewer than 20000 for sea urchins, and 30000-40000 functional genes for mammals (Futuyma, 1998) can be considered. Unfortunately, technical issues (high costs, labor and time expenditure) severely limit the availability of these data. Additionally, the wide diversity of organisms, even in simple ecosystems, will always limit data available for a proper evaluation. Therefore, a pragmatic procedure is required to estimate the information content of the genome.

The proposal of Marques et al. (1997) envisages the estimation of the total amount of DNA per cell nucleus ( $C$-value), which is assumed 'proportional' to the information content of the genome, accounting for organisms structural 'complexity'. Nuclear DNA data ( $C$-values) are available in the literature for some organisms and $C$-values were determined by FCM for a variety of organisms, after appropriate modifications of described methodologies, depending on particular characteristics of organisms, viz. size and hardness (Table 2).

In terms of laboratory facilities and practice, the proposal by Marques et al. (1997) is fully feasible. It brings ecological modelling 'closer' to real systems, as the estimation of the weighing factors depends upon the determination of biological parameters ( $C$-values). Additionally, more discrete parameters $(\beta)$ may be estimated with data at lower levels, whereas previous values were estimated with data assumed as reasonable or weighed among higher groups (Phylum or Class). Obviously, a theoretically discussion is required about the relation of DNA contents and the genome size. Table 2, although not exhaustive, illustrates that $C$-values vary widely in closely related species (MacGregor, 1982; Gold et al., 1992; Gambi et al., 1997). Also, in some phyla, the range of $C$-values can be either narrow or very wide (Wagner et al., 1980; Levin, 1994). Moreover, some organisms with less morphological 'complexity' than mammals exhibit larger $C$ values, evidencing a lack of correlation between structural 'complexity' and total DNA content (Cavalier-Smith, 1985). These findings reinforce the concept of the ' $C$-value paradox' (see $\mathrm{Fu}$ tuyma, 1998), essentially consequence of the repetitive (noncoding) DNA sequences in eukaryotic genome (Li and Graur, 1991), which may account for more than $50 \%$ of the total genomes (John and Miklos, 1988). Consequently, instead of $C$-values to calculate weighing factors $\beta$ for each species, the lowest (known) $C$-value in different groups of organisms (Table 3 ) is preferable. These values will hopefully provide a procedure to 'weight' the biomass (in terms of exergy) of organisms from different groups according to the assumed level of complexity for each group, and, therefore, for the system. Nevertheless, knowing that non-repetitive DNA genome relates better to the complexity of organisms (see Levin, 1994), as illustrated in Table 1, development of methodologies to estimate the non-repetitive DNA content of genome (e.g. the technique of reassociation kinetics) is welcome to replace the FCM estimation of total nuclear DNA.

Values for the parameter $\beta$ were previously estimated using the number of encoded amino acids of genome $(700 \mathrm{~g})$, assuming different number of genes $(g)$ for each organism and that each gene codes for an average number of 700 amino acids (Jørgensen et al., 1995). In a different direction, we consider the $C$-value as an estimate of the overall coding capacity of the genome and used it in the evaluation of $\beta$. According with the assumptions, these estimates for the information 
content' of genome must be understood as topmost limit values (corresponding to minimum probabilities). Therefore, figures differing significantly were estimated from these different approaches (Table $3)$. Nevertheless, the values relate to biological parameters ( $C$-values), which were selected during the evolution processes.

It is obvious that an estimate of the 'information content' from the total DNA content may suffer from a strong bias. Therefore, as consequence of the ' $C$-value paradox', estimates of exergy based on this approach are biased as well, and should be taken with caution. Additionally, the total DNA may affect biological events, from cell size and division, to ecological effects. Higher $C$-values are frequently associated with species having a slower development (Bennet, 1982; Rees et al., 1982; Sessions and Larson, 1987), and closely related organisms may reach similar dimensions with different number of cells (MacGregor, 1982). Therefore, before any definite conclusions regarding the merit of the approach proposed by Marques et al., (1997), comparative studies are required, along with other ecological indicators (e.g. diversity indices, ascendancy, energy), aiming to assess the efficiency in capturing any additional information regarding ecosystems health and integrity.

\section{Acknowledgements}

The authors wish to thank Miguel Pardal, Ulisses Miranda and colleagues at IMAR for their assistance during field work. Authors are recognised to Maria Henriqueta, Director of HCC, for the facilities of FCM and collaboration in used methodologies. This work was supported by the Portuguese Science and Technology Foundation (Projects: PBICT/MAR/2253/95 and PRAXIS/P/MGS/ $11238 / 1998)$ and by the EUROPEAN UNION (project FMRX-CT96-0051).

\section{References}

Ahern, J.E., 1980. The Exergy Method of Energy Systems Analysis. Wiley, New York. Referred in: Schneider and Kay 1994.
Bass, B., 1998. Applying thermodynamic orientors: goal functions in the holling figure-eighth model. In: Müller, F., Leupelt, M. (Eds.), Ecotargets, Goal Functions, and Orientors. Springer-Verlag, Berlin, pp. 193-208.

Bendoricchio, G., Jørgensen, S.E., 1997. Exergy as goal function of ecosystems dynamic. Ecol. Model. 102, 5-15.

Bennet, M.D., 1982. Nucleotypic basis of the spatial ordering of chromosomes in eukaryotes and the implication of the order for genome evolution and phenotypic variation. In: Dover, G.A., Flavell, R.B. (Eds.), Genome Evolution. Academic Press, New York, pp. 239-261.

Bröring, U., Wiegleb, G., 1998. Ecological orientors: pattern and process of succession in relation to ecological orientors. In: Müller, F., Leupelt, M. (Eds.), Ecotargets, Goal Functions, and Orientors. Springer-Verlag, Berlin, pp. 34-62.

Brzustowski, T.A., Golem, P.J., 1978. Second Law Analysis of Energy Processes, part 1. Exergy - An Introduction. Transactions of the Canadian Society of Mechanical Engineers, vol 4, 4: pp. 209-218. Referred in: Schneider and Kay1994.

Cavalier-Smith, T., 1978. Nuclear volume control by nucleoskeletal DNA, selection for cell volume and cell growth rate, and the solution for the DNA $C$-value paradox. J. Cell. Sci. 34, 247-278.

Cavalier-Smith, T., 1985. The Evolution of Genome Size. Wiley, Chichester.

Fonseca, J.C., Marques, J.C., Pardal, M.A., Soren, N., Jørgensen, S.E., 1998. Applying thermodynamic orientors as indicators in environmental management: exergy and its estimation. ISEM, 49th Annual Meeting of AIBS, Baltimore, Maryland, USA, 1998.

Fuliu, Xu., 1997. Exergy and structural exergy as ecological indicators for the state of the Lake Chaolu ecosystem. Ecol. Model. 99, 41-49.

Futuyma, D.J, 1998. Evolutionary Biology, 3rd edition. Sinauer Associates, Sunderland, MA.

Gailbraith, D.W., 1989. Analysis of higher plants by flow cytometry and cell sorting. Int. Rev. Cytol. 116, 165-228.

Gailbraith, D.W., Harkins, K.R., Maddox, J.M., Ayers, N.M., Sharma, D.P., Firoozabady, E., 1983. Rapid flow cytometry of cell cycle in intact plant tissues. Science 220, 1049-1051.

Gambi, M.C., Ramella, L., Sella, G., Protto, P., Aldieri, E., 1997. Variation in genome size in benthic polychaetes: systematic and ecological relationships. J. Mar. Biol. Ass. UK 77, 1045-1057.

Gold, J.R., Ragland, C.J., Woolley, J.B., 1992. Evolution of genome size in North American fishes. In: Mayden, R.L. (Ed.), Systematics, Historical Ecology, and North American freshwater fishes. Stanford University Press, Stanford, CA.

John, B., Miklos, G.L.G., 1988. The Eukaryotic Genome in Development and Evolution. Allen and Urwin, London.

Jørgensen, S.E., 1992a. Exergy and ecology. Ecol. Model. 63, $185-214$.

Jørgensen, S.E., 1992b. Development of models to account for changes in species composition. Ecol. Model. 62, 195-208.

Jørgensen, S.E., 1992c. In: Pattern, A. (Ed.), Integration of Ecosystem Theories. Kluwer, Dordrecht.

Jørgensen, S.E., Mejer, H., 1977. Ecological buffer capacity. Ecol. Model. 3, 39-61. 
Jørgensen, S.E., Mejer, H., 1979. A holistic approach to ecological modeling. Ecol. Model 7, 169-189.

Jørgensen, S.E., Mejer, H., 1981. Exergy as a key function in ecological models. In: Mitsch, W.J., Bosserman, R.W., Klopatek, J.M. (Eds.), Energy and Ecological Modeling. Elsevier, Amsterdam, pp. 587-590.

Jørgensen, S.E., 1994. Review and comparison of goal functions in system ecology. Vie Milieu 44 (1), 11-20.

Jørgensen, S.E., Nielsen, S.N., Mejer, H., 1995. Emergy, environ exergy and ecological modeling. Ecol. Model. 77, 99-109.

Jørgensen, S.E., Padisak, J., 1996. Does the intermediate disturbance hypothesis comply with thermodynamics? Hydrobiologia 323, 9-21.

Jørgensen, S.E., Nielsen, S.N., 1998a. Thermodynamic orientors: exergy as a goal function in ecological modeling and as an ecological indicator for the description of ecosystem development. In: Müller, F., Leupelt, M. (Eds.), Ecotargets, Goal Functions, and Orientors. Springer-Verlag, Berlin, pp. 63-86.

Jørgensen, S.E., Nielsen, S.N., 1998b. Thermodynamic orientors: a review of goal functions and ecosystem indicators. In: Müller, F., Leupelt, M. (Eds.), Ecotargets, Goal Functions, and Orientors. Springer-Verlag, Berlin, pp. 123-135.

Levin, B., 1994. Genes V. Oxford University Press, London.

Li, W.-H., Graur, D., 1991. Fundamentals of Molecular Evolution. Sinauer Associates, Sunderland, MA.

MacGregor, H.C., 1982. Big chromossomes and speciation amongst Amphibia. In: Dover, G.A., Flavell, R.B. (Eds.), Genome Evolution. Academic Press, New York.

Marques, J.C., Pardal, M.Â., Neilsen, S.N., Jørgensen, S.E., 1997. Analysis of the properties of exergy and biodiversity along an estuarine gradient of eutrophication. Ecol. Model. 102, 155-167.

Marques, J.C., Pardal, M.A., Nielsen, S.N., Jørgensen, S.E., 1998a. Thermodynamic Orientors: Exergy as a Holistic Ecosystem Indicator: A Case Study. In: Müller, F., Leupelt, M. (Eds.), Ecotargets, goal functions, and orientors. Theoretical concepts and interdisciplinary fundamentals for an integrated, system-based environmental management. Springer-Verlag, Berlin, Chapter 2.5, pp. 87-101.

Marques, J.C, Nielsen, S.N., Jørgensen, S.E., 1998b. Applying Thermodynamic Orientors: the Use of Exergy as an Indicator in Environmental Management. In: Müller, F., Leupelt, M. (Eds.), Ecotargets, goal functions, and orientors. Theoretical concepts and interdisciplinary fundamentals for an integrated, system-based environmental management. Springer-Verlag, Berlin, Chapter 5.3, pp. 481-489.

Mejer, H.F., Jørgensen, S.E., 1979. Energy and ecological buffer capacity. In: Jørgensen, S.E. (Ed.), State-of-the-Art of Ecological Modeling: Environmental Sciences and Applications, Proceedings of the 7th Conference on Ecological Modeling, 28 August-2 September 1978, Copenhagen. International Society for Ecological Modeling, Copenhagen, pp. 829-846.

Müller, F., 1997. State-of-the-art in ecosystem theory. Ecol. Model. 100, 135-161.

Nielsen, S.N., 1990. Application of exergy in structural-dynam- ical modelling. Verh. Int. Ver. Limnol. 24, 641-645.

Patten, B.C., 1998. Network orientors: steps toward a cosmography of ecosystems: orinetors for directional development, self-organization, and autoevolution. In: Müller, F., Leupelt, M. (Eds.), Ecotargets, Goal Functions, and Orientors. Springer-Verlag, Berlin, pp. 137-160.

Prigogine, I., 1980. From Being to Becoming: Time and complexity in the physical science. W.H. Freeman, Oxford.

Rayburn, A.L., 1993. Comparative studies of genome content. In: Methods in Enzimology, pp. 204-212.

Rees, H., Jenkins, G., Seal, A.G., Hutchinson, J., 1982. Assays of the phenotypic effects of changes in DNA amounts. In: Dover, G.A., Flavell, R. (Eds.), Genome Evolution. Academic Press, London, pp. 287-297.

Schneider, E.D., Kay, J.J., 1994a. Life as a Manifestation of the Second Law of Thermodynamics. Math. Comp. Model. 9 (6-8), 25-48.

Schneider, E.D., Kay, J.J., 1994b. Complexity and thermodynamics: towards a new ecology. Futures 24 (6), 626-647.

Schneider, E.D., Kay, J.J., 1995. Order from Disorder: the Thermodynamics of Complexity in Biology. In: Murphy, M.P., O’Neill, L.A.J. (Eds.), Whats is Life: The Next Fifty Years: Reflections on the Future of Biology, Cambridge University Press, Cambridge, pp. 161-172.

Schrödinger, E., 1944. What is Life? Cambridge University Press, Cambridge.

Sessions, S.K., Larson, A., 1987. Developmental correlates of genome size in plethodontid salamanders and their implications for genome evolution. Evolution 41, 1239-1251.

Shapiro, H.M., 1995. Practical Flow Cytometry, 3rd Edition. Wiley, New York.

Shieh, J.H., Fan, L.T., 1982. Estimation of energy (enthalpy) and energy (availability) contents in structurally complicated materials. Energy Resour. 6, 1-46.

Søndergaard, M., Jeppsen, E., Mortensen, E., Dall, P., Kristensen, P., Sortkjær, O., 1990. Phytoplankton biomass reduction after planktivorous fish reduction in a shallow, eutrophic lake: a combined effect of reduced internal P-loading and increased zooplankton grazing. Hydrobiologia 200/ 201, 229-240.

Svirezhev, Y., 1998. Thermodynamic Orientors: How to Use Thermodynamic Concepts in Ecology. In: Müller, F., Leupelt, M. (Eds.), Ecotargets, goal functions, and orientors: theoretical concepts and interdisciplinary fundamentals for an integrated, system-based environmental management. Springer-Verlag, Berlin, Chapter 2.6, pp. 102-122.

Ulanowicz, R.E., 1998. Network orientors: theoretical and philosophical considerations why ecosystems may exhibit a propensity to increase in ascendancy. In: Müller, F., Leupelt, M. (Eds.), Ecotargets, Goal Functions, and Orientors. Springer-Verlag, Berlin, pp. 176-192.

Wagner, R.P., Judd, B.H., Saunders, B.G., Richardson, R.H., 1980. Introduction to Modern Genetics. Wiley, New York.

Wall, G., 1986. Exergy — a Useful Concept. Physical Resource Theory Group, Chalmers University Of Technology, Göteborg, Sweden.

Zhou, J., Ma, S., Hinman, G.W., 1996. Ecological exergy analysis: a new method for ecological energetics research. Ecol. Model. 84, 291-303. 